\title{
Understanding Peptide Binding in Class A G Protein-Coupled Receptors
}

\author{
Irina G. Tikhonova, Veronique Gigoux, and Daniel Fourmy \\ School of Pharmacy, Medical Biology Centre, Queen's University Belfast, Belfast, Northern Ireland, United Kingdom, (I.G.T.) and \\ INSERM ERL1226-Receptology and Therapeutic Targeting of Cancers, Laboratoire de Physique et Chimie des Nano-Objets, \\ CNRS UMR5215-INSA, Université de Toulouse III, Toulouse, France (V.G., D.F.)
}

Received January 22, 2019; accepted June 13, 2019

\section{ABSTRACT}

Many physiologic processes are controlled through the activation of G protein-coupled receptors (GPCRs) by regulatory peptides, making peptide GPCRs particularly useful targets for major human diseases such as diabetes and cancer. Peptide GPCRs are also being evaluated as next-generation targets for the development of novel antiparasite agents and insecticides in veterinary medicine and agriculture. Resolution of crystal structures for several peptide GPCRs has advanced our understanding of peptide-receptor interactions and fueled interest in correlating peptide heterogeneity with receptor-binding properties. In this review, the knowledge of recently crystalized peptide-GPCR complexes, previously accumulated peptide structure-activity relationship studies, receptor mutagenesis, and sequence alignment are integrated to better understand peptide binding to the transmembrane cavity of class A GPCRs. Using SAR data, we show that peptide class A GPCRs can be divided into groups with distinct hydrophilic residues. These characteristic residues help explain the preference of a receptor to bind the C-terminal free carboxyl group, the C-terminal amidated group, or the $\mathrm{N}$-terminal ammonium group of peptides.

\section{Introduction}

Over 50 peptides released by endocrine and neuronal tissues play roles as circulating hormones, neurotransmitters, local regulators, or all of these at once, controlling human development, reproduction, physiology, and behavior. This regulatory peptide system is a major target of therapeutic intervention in the control of body function. Targeting the regulatory peptide system has been critical in oncology, endocrinology, neuroscience, and many other areas (Lau and Dunn, 2018).

Biologically active peptides are produced from large precursor molecules via proteolytic cleavage and other post-translational modifications, such as amidation, acetylation, cyclization, sulfation, glycosylation, and phosphorylation. Although some peptides are characterized by a common motif (e.g., RFamide

Work described herein was supported in part by grants from NEXTLPCNO-CNRS (to I.G.T., V.G. and D.F.) and the Biotechnology and Biosciences Research Council [BB/R007101/1] (to I.G.T.).

https://doi.org/10.1124/mol.119.115915. peptides are characterized by a Arg-Phe-NH2 sequence at their C-terminus), overall they have great diversity in size, chemistry, and structure.

Most regulatory peptides elicit their biologic responses by binding to over $100 \mathrm{G}$ protein-coupled receptors (GPCRs), also known as seven transmembrane-spanning receptors. Among the six known classes of GPCRs, receptors from classes $A$ and $B$ bind regulatory peptides. In particular, a large number of regulatory peptides bind to class A GPCRs.

A “message-address" concept of peptide binding was introduced by Schwyzer in the 1970s following studies on adrenocorticotropin peptide truncation (Schwyzer, 1977). Thus, the adrenocorticotropin N-terminus-which is important for receptor activation acts as a 'message', while the peptide C-terminus enhancing the activity represents an 'address'. This concept was further explored in structure-activity relationship (SAR) studies of opioid peptide dynorphin (Chavkin and Goldstein, 1981) and design of opioid agonists and antagonists (Portoghese et al., 1988, 1993). From these studies, it was

ABBREVIATIONS: APLNR, apelin receptor; $\mathrm{AT}_{1}$ and $\mathrm{AT}_{2}$, angiotensin receptors; DAMGO, H-Tyr-D-Ala-Gly-N(Me)Phe-Gly-OH, (2S)-2-[[2-[[(2R)-2[[(2S)-2-amino-3-(4-hydroxyphenyl)propanoyl]amino]propanoyl]amino]acetyl]-methylamino]- $\mathrm{N}$-(2-hydroxyethyl)-3-phenylpropanamide; DIPP-NH2, $\mathrm{H}$-Dmt-Tic-Phe-Phe-NH2; DOR, opioid receptor; EMPA, N-ethyl-2-[(6-methoxy-pyridin-3-yl)-(toluene-2-sulfonyl)-amino]- $N$-pyridin-3-ylmethylacetamide; $\mathrm{ET}_{\mathrm{A}}, \mathrm{ET}_{\mathrm{B}}$, endothelin receptors; GPCR, G protein-coupled receptor; KOR, opioid receptor; MOR, opioid receptor; $\mathrm{MOP}$, opioid receptor; $\mathrm{NK}_{1}, \mathrm{NK}_{2}, \mathrm{NK}_{3}$, neurokinin/tachykinin receptors; NMU1, NMU2, neuromedin-U receptors; NOP, opioid receptor; NPY 1 , NPY, $\mathrm{NPY}_{4}$, $\mathrm{NPY}_{5}$, neuropeptide $\mathrm{Y}$ receptors; NTS1, NTS2, neurotensin receptors; OX ${ }_{1}, \mathrm{OX}_{2}$, orexin receptors; PAR1, PAR2, PAR3, PAR4, PAR5, proteinaseactivated receptors; PMX53, (2S)-2-acetamido- $N$-[(3S, 9S,12S,15R,18S)-15-(cyclohexylmethyl)-9-[3-(diaminomethylideneamino)propyl]-12-(1H-indol-3ylmethyl)-2,8,11,14,17-pentaoxo-1,7,10,13,16-pentazabicyclo[16.3.0]henicosan-3-yl]-3-phenylpropanamide; SAR, structure-activity relationship; SB-674042, 5-(2-fluorophenyl)-2-methyl-4-thiazolyl][2(S)-2-[(5-phenyl-1,3,4-oxadiazol-2-yl)methyl-1-pyrrolidinyl]methanone. 

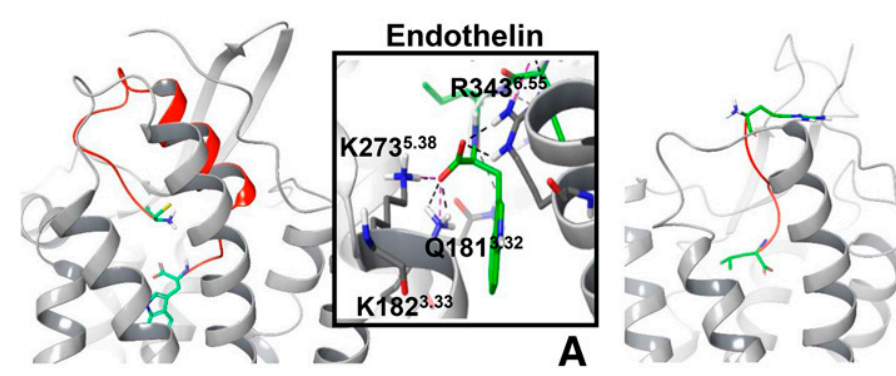

\section{Neuroteinsin}
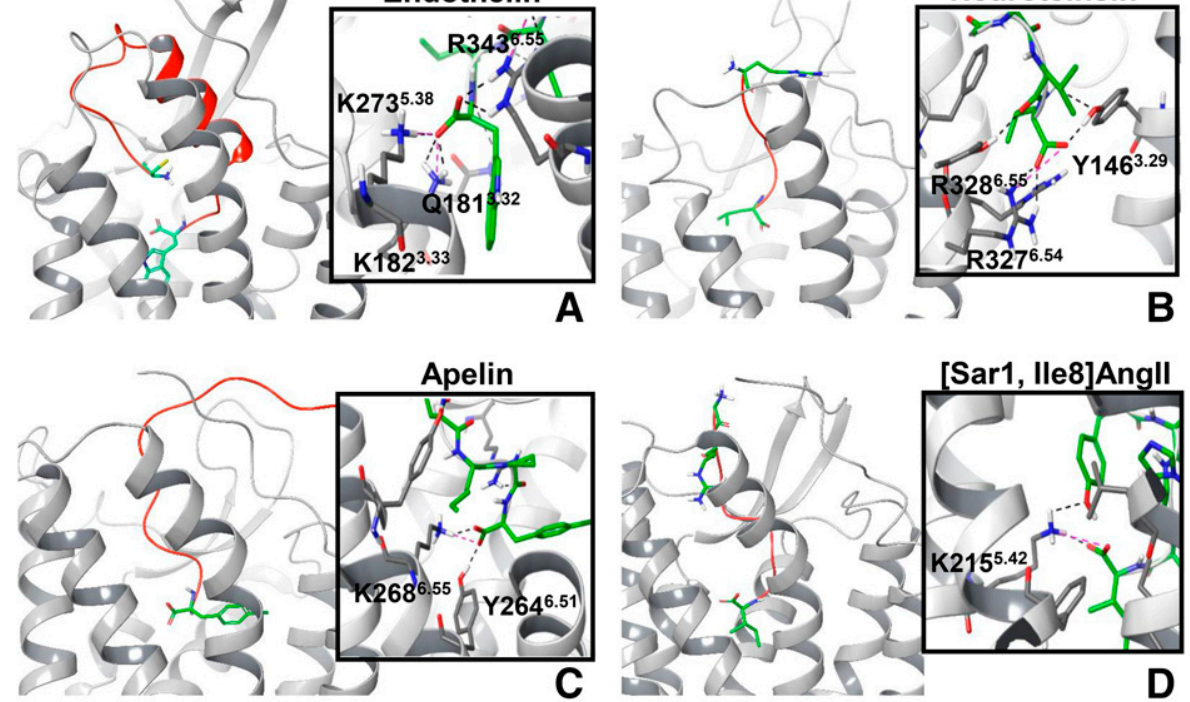

[Sar1, lle8]Angll
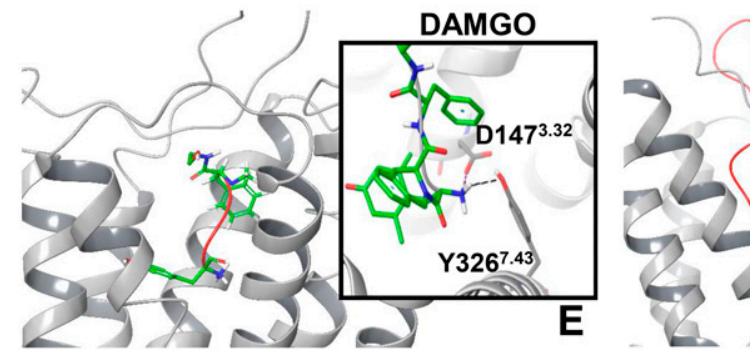

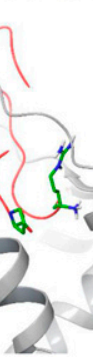

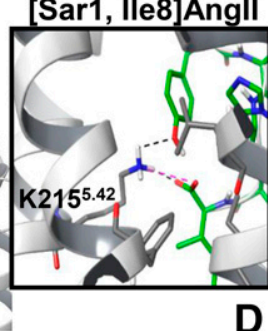

D

shown that there are separate recognition sites for the address and message moieties of a peptide in the receptor.

In recent years, remarkable progress had been made in the structural biology of GPCRs, mostly owing to the determination of crystallographic structures of several family members, including peptide GPCRs. Currently, 12 peptide class A and four peptide class B GPCRs have been crystallized in complex with either peptides or nonpeptide ligands. A comprehensive overview of the crystal structures of peptide GPCRs with regard to peptide and nonpeptide ligand binding has been recently reviewed by $\mathrm{Wu}$ et al. (2017). The newly available structural information, in combination with peptide structureactivity studies accumulated over years, not only describes atomic details of peptide-receptor interactions for the crystalized GPCRs but also helps in understanding how these structurally diverse molecules bind within the peptide GPCR subfamily. In this review, using available crystal structures of peptide GPCRs in conjunction with peptide SAR studies, receptor mutagenesis, and sequence analysis, we analyze binding of the C-terminus or N-terminus of regulatory peptides to the transmembrane cavity of the class A GPCRs. We show that peptide SAR data has effectively subdivided the class A GPCR binding-site residues into different groups having distinct hydrophilic residues. These characteristic hydrophilic residues are linked to the preference of the receptor to bind the C-terminal free carboxyl group, the C-terminal amidated group, or the $\mathrm{N}$-terminal ammonium group of peptides.

\section{X-Ray Structures of GPCRs Bound to Peptides}

The crystal structures of the following class A peptide-GPCRs complexed with peptide agonists or antagonists are currently

available: apelin (APLNR), angiotensin $\left(\mathrm{AT}_{1}\right)$, neurotensin $\left(\mathrm{NTS}_{1}\right)$, endothelin $\left(\mathrm{ET}_{\mathrm{B}}\right)$, opioid (MOR and DOR), chemokine (US28 and CXCR4), and component peptide $\left(\mathrm{C}^{2} \mathrm{a}_{1}\right)$ receptors $(\mathrm{Wu}$ et al., 2010; White et al., 2012; Burg et al., 2015; Fenalti et al., 2015; Qin et al., 2015; Shihoya et al., 2016; Ma et al., 2017; Asada et al., 2018; Koehl et al., 2018; Liu et al., 2018). Furthermore, subtypes of the protease-activated (PAR1 and PAR2), chemokine (CXCR4, CCR2, CCR5 and CCR9), opioid (MOR, KOR, DOR, and NOP), orexin $\left(\mathrm{OX}_{1}\right.$ and $\left.\mathrm{OX}_{2}\right)$, angiotensin $\left(\mathrm{AT}_{1}\right.$ and $\left.\mathrm{AT}_{2}\right)$, neuropeptide (NPY1), C5a, and neurokinin $\left(\mathrm{NK}_{1}\right)$ receptors are crystallized in complex with nonpeptide orthosteric and/or allosteric antagonists (Wu et al., 2017; Liu et al., 2018; Robertson et al., 2018; Yang et al., 2018; Yin et al., 2018; Schoppe et al., 2019).

As expected, peptides tend to bind to GPCRs in many different conformations. However, in general, one part of the peptide is buried in the helical cavity, whereas another part forms interactions with the extracellular loops and the N-terminus of GPCRs. Peptides, including apelin, angiotensin, endothelin, neurotensin, and cyclic PMX53, point the C-terminus inside the helical bundle, whereas peptides binding to the opioid and chemokine receptors (Fig. 1) bind in the reverse orientation with the $\mathrm{N}$-terminus pointing to the receptor helical side.

Polar interactions are the primary driving force for peptide recognition and binding. To identify the polar interactions, hydrogen atoms were added and optimized in the crystal structures; and hydrogen bonds and salt bridges between the peptide and the receptor were then calculated using the Maestro software (Maestro 9.9, 2014; Schrodinger, LLC, New York, NY) with default setting (Table 1). Given that the 
TABLE 1

Hydrogen bond (H) and salt bridge (SB) interactions between a peptide and the helical cavity from the available crystal structures of class A GPCRs bound to a peptide

\begin{tabular}{|c|c|c|c|c|c|c|c|}
\hline Peptide & Receptor & $\begin{array}{l}\text { Overall Number } \\
\text { of Contacts }\end{array}$ & $\begin{array}{l}\text { Number of Contacts with } \\
\text { Peptide Side Chains }\end{array}$ & $\begin{array}{l}\text { Number of Contacts } \\
\text { with Peptide Backbone }\end{array}$ & $\begin{array}{l}\text { Number of Contacts with } \\
\text { Peptide Terminal Group }\end{array}$ & $\begin{array}{l}\text { Number of Peptide } \\
\text { Residues within the } \\
\text { Cavity }\end{array}$ & $\begin{array}{l}\text { PDB } \\
\text { Code }\end{array}$ \\
\hline Apelin & APLNR & 8 & $2 \mathrm{H}+1 \mathrm{SB}^{a}$ & $2 \mathrm{H}$ & $2 \mathrm{H}+1 \mathrm{SB}$ & 6 & $5 \mathrm{VBL}$ \\
\hline Neurotensin & $\mathrm{NTS}_{1}$ & 6 & $1 \mathrm{H}$ & $1 \mathrm{H}$ & $3 \mathrm{H}+1 \mathrm{SB}$ & 4 & 4GRV \\
\hline Endothelin & $\mathrm{ET}_{\mathrm{B}}$ & 16 & $4 \mathrm{H}+1 \mathrm{SB}$ & $6 \mathrm{H}$ & $3 \mathrm{H}+2 \mathrm{SB}$ & 16 & $5 \mathrm{GLH}$ \\
\hline [Sar1, Ile8] & $\mathrm{AT}_{2}$ & 12 & $3 \mathrm{H}+1 \mathrm{SB}$ & $6 \mathrm{H}$ & $1 \mathrm{H}+1 \mathrm{SB}$ & 6 & $5 \mathrm{XJM}$ \\
\hline AngII & & & & & & & \\
\hline DIPP-NH2 & DOR & 4 & $1 \mathrm{H}$ & & $2 \mathrm{H}+1 \mathrm{SB}$ & 3 & 4RWD \\
\hline DAMGO & MOR & 4 & $1 \mathrm{H}$ & & $2 \mathrm{H}+1 \mathrm{SB}$ & 5 & $6 \mathrm{DDF}$ \\
\hline CX3CL1 & US28 & 5 & $1 \mathrm{H}$ & $3 \mathrm{H}$ & $1 \mathrm{H}$ & 7 & 4XT3 \\
\hline CX3CL1/Nb7 & US28 & 7 & $2 \mathrm{H}$ & $4 \mathrm{H}$ & $1 \mathrm{H}$ & 11 & $4 \mathrm{XT} 1$ \\
\hline $\begin{array}{l}\text { vMIP-II } \\
\text { late }\end{array}$ & CXCR4 & 13 & $6 \mathrm{H}+2 \mathrm{SB}$ & $2 \mathrm{H}$ & $2 \mathrm{H}+1 \mathrm{SB}$ & 9 & 4RWS \\
\hline CVX15 & CXCR4 & 10 & $6 \mathrm{H}+3 \mathrm{SB}$ & & $1 \mathrm{H}$ & 6 & 3OE0 \\
\hline cyclicPMX53 & $\mathrm{C} 5 \mathrm{a}_{1}$ & 12 & $6 \mathrm{H}+1 \mathrm{SB}$ & $5 \mathrm{H}$ & & 3 & $6 \mathrm{C} 1 \mathrm{R}$ \\
\hline
\end{tabular}

${ }^{a}$ Hydrogen bond criteria: $3 \AA$ for the maximum distance between donor and acceptor atoms, $90^{\circ}$ and $60^{\circ}$ for donor and acceptor minimum angles, respectively. Salt bridge criteria: the maximum distance between atoms is $5 \AA$.

extracellular loops and the N-terminus vary in GPCRs and the helical bundle is conserved, we analyzed interactions of the peptides with the helical bundle to compare the binding of the peptides. The peptides form multiple hydrogen bonds and salt bridges with the residues of the transmembrane helices via side chains, backbone, and terminal groups (Table 1). Interestingly, the terminal charged group of peptides located within the helical bundle is engaged in several polar interactions (Fig. 1). Thus, the C-terminal carboxyl group of angiotensin, apelin, endothelin, and neurotensin forms salt bridges and hydrogen bonds with positively charged lysine and arginine residues. The $\mathrm{N}$-terminal ammonium group of the peptides in the opioid and chemokine receptors is engaged in an ionic interaction with an aspartate residue (Fig. 1).

Earlier SAR studies utilizing fragments and amidated or esterified analogs of angiotensin, endothelin, and neurotensin have shown that the C-terminus together with the free carboxyl group is required for the activity of these peptides (Rioux et al., 1975; Rovero et al., 1990; Labbe-Jullie et al., 1998). Indeed, the ionic interaction patterns observed in the crystal structures confirm the SAR studies.

The correlation between direct and indirect structural information of peptide binding suggests that SAR data of peptide terminal ends could be further linked with available structural information to gain insight into interactions of peptides with not yet crystalized GPCRs. A question then arises as to whether the large heterogeneity of peptide ligands and ability to activate different GPCRs can be linked or classified somewhat using binding characteristics of the peptide C- or $\mathrm{N}$-terminal groups interacting with the transmembrane helices. In an attempt to address this question, we propose to integrate the knowledge of binding-site residues gained from the crystal structures with peptide SAR studies and sequence analysis of the class A GPCRs.

\section{Class A Receptor Grouping with Peptide SAR and Hydrophilic Binding Site Residues as a Basis}

We collected SAR data from the literature for 47 peptides binding to class A GPCRs to compare peptide binding properties. Table 2 shows a sequence of peptides or short, active peptide fragments, derived from peptide truncation studies and peptide end-terminal functional groups important for activity and obtained from analog studies. The peptides are grouped on the basis of the importance of the peptide terminal end to activity. The $\mathrm{C}$-terminus of the peptide contains a free carboxyl or amide group. For the first 11 peptides in Table 2, the free carboxyl group is important for peptide activity, whereas for a large number of peptides (19 in the table) amidation of the carboxyl group is favorable for activity. Amidation is the most common post-translational modification of peptides. For many peptides, this modification not only improves peptide stability and delivery but is also required for activity, as determined in the SAR studies (Table 2). The table also includes a number of regulatory peptides for which the $\mathrm{N}$-terminus or the cyclic portion of the peptide structure is important for activity. Furthermore, we review available receptor mutagenesis and receptor-peptide modeling studies and show in Table 2 the peptide terminal end that is predicted to bind inside the helical bundle. From available published data, it appears that the terminal end of peptides, which is critical for activity ("message" moiety), is pointed to the helical bundle.

Initially, 35 residues lining the helical cavity of the peptide class A GPCRs were selected using the "ligand binding pocket for class A" option in the GPCRDB server (ww.gpcrdb.org) to relate the binding properties of the peptide GPCRs with the collected peptide SAR data. In addition to the human receptors, several other orthologs (bovine, chimpanzee, guinea pig, mouse, rat, and rabbit) were considered in the amino acid residue alignment. The Ballesteros-Weinstein index (Ballesteros and Weinstein, 1995) was used for the residue selection and comparison among GPCRs. Next, taking into consideration the polar interactions in the crystalized peptide-GPCR complexes, the number of residues for the analysis was reduced to 25 by focusing only on residue positions with a high occurrence of hydrophilic residues. The alignment of 25 binding site residues was split into five groups on the basis of the binding of the peptide terminal end that is important for activity (Fig. 2). Figure 2 shows the alignment of binding site residues for the human receptors and the conservation score for hydrophilic residues in each residue position from the analysis of receptor orthologs. In the next sections, we will assess each of the receptor groups and highlight patterns of residues anchoring the "message" peptide end. 


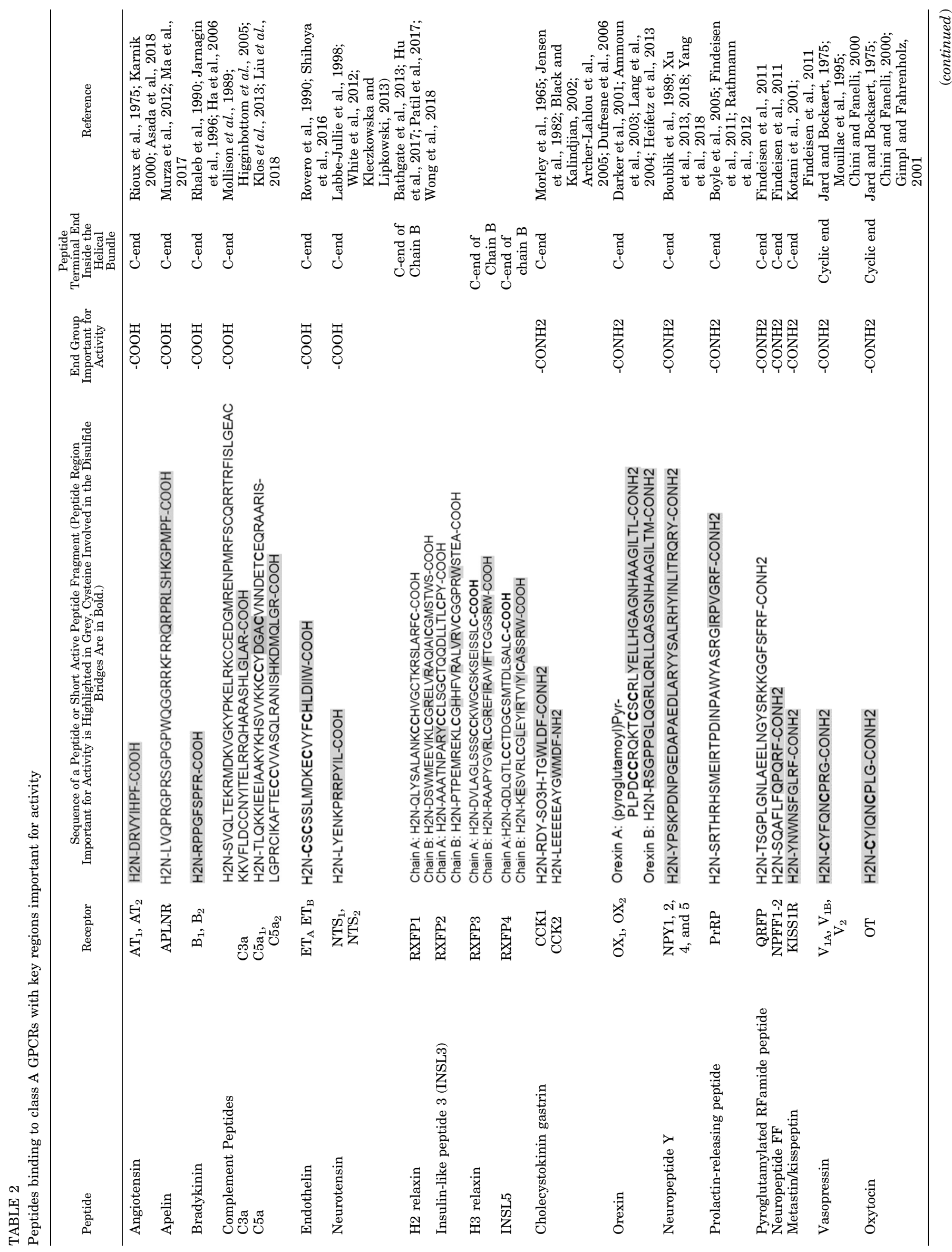

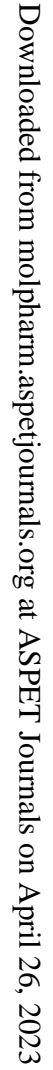




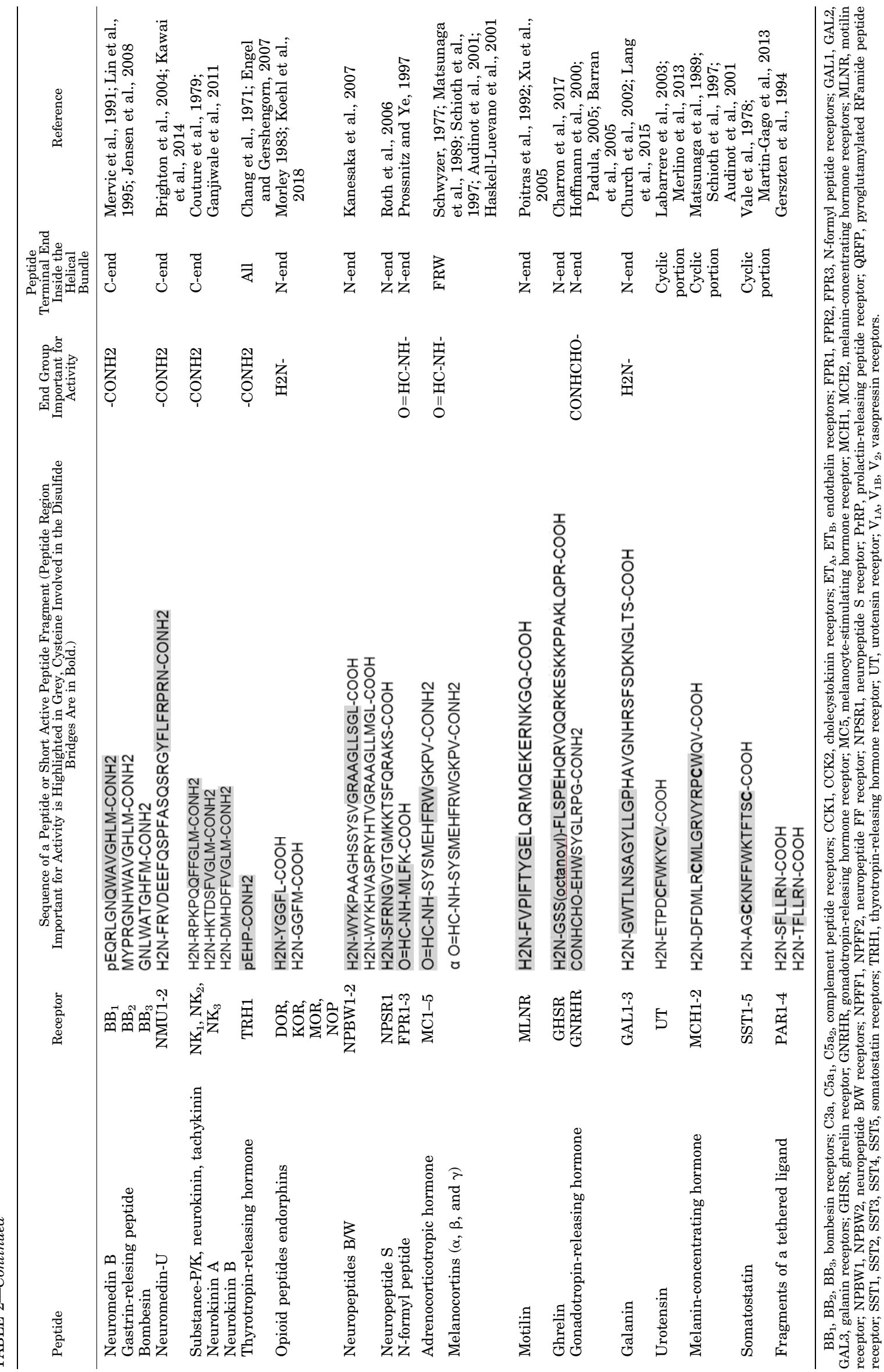


A

$\mathrm{AT}_{1} \quad$ WYTSVSAHRPLGKHOFTDVVDTMPI $\mathrm{AT}_{2}$ WYYGLTTFRS IAKFHLTDAIDLLPI

APLNR WYTSIFVLRELGSYHVKYMLMNEPT C3a SHLPIVVYRLITRYHFGSLLMSDHI $\mathrm{C}^{5} \mathrm{a}_{1}$ LSIPILSYREVARYQTGMSLKKDSV $\mathrm{C} \mathrm{a}_{2}$ LPIPILSYREVTRYHLGLTALREPV $\mathrm{ET}_{\mathrm{A}} \quad$ NKLPQKEGFQKDLLHSRKKLLLDYI $\mathrm{ET}_{\mathrm{B}} \quad$ NKLPQKEGEKKDLLHSRKLLLVDYI $N_{T} S_{1}$ ENFYRDMTMVVINYHRRFCYHYYMN $\mathrm{NTS}_{2}$ ESFYHEMIMLF INYHRRYCYHYYMN RXFP1 IFDGAIPNKAYSIIFVKSLGTISWI RXFP2 VFDGAMPNKSYSIVFVKSLDTMSWI RXFP3 WENSTSSFSLYHKNQLTSIQVYFPV RXFP4 WESLTVTFGLYQRNHVTGVQTYFPT $B_{1} \quad$ WNINIKTLRHRILYHFAEFIDLLQN $\mathrm{B}_{2}$ WTINISMFRETNLFQSTDTIDVTQS

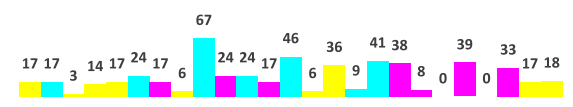

\section{B}

\begin{tabular}{|c|c|}
\hline $\mathrm{NPY}_{1}$ & TYTPQCFYQRYTLLTFNFDH \\
\hline $\mathrm{NPY}_{2}$ & TPQGLFRGYSSLHFQVDYK \\
\hline $\mathrm{NPY}_{4}$ & TYTAQCFNSRYTLLHFNEDGN \\
\hline $\mathrm{NPY}_{5}$ & TSVPQCLFHRFTLLHFHTDFK] \\
\hline $\mathrm{OX}_{1}$ & AQVMPYHF ISLNKRVY \\
\hline $\mathrm{OX}_{2}$ & PYHFISLNK \\
\hline $1 \mathrm{~A}$ & OIVIME $E \perp$ \\
\hline IB & VIFPYLIEFVQ \\
\hline 2 & VQMQIFRYVIFFV \\
\hline $\mathrm{T}$ & PYIIFFVQ \\
\hline CK1 & WHLLFA \\
\hline CK2 & GYYIRWSLVYANRASGA \\
\hline $\mathrm{RFP}$ & SWQQQYTIFHVHIEIKM \\
\hline $\operatorname{rRP}$ & PATRYALLHFNRD \\
\hline $\mathrm{PFF} 1$ & GSTLRYTLLWLLIL \\
\hline $\mathrm{PFF} 2$ & GSMLRYTLLWLMSDNIY) \\
\hline KISS1R & QQVLHEFANIQFLQAAYAK \\
\hline $\mathrm{BB}_{1}$ & LEFSPHS INHLYRSHMIT \\
\hline $\mathrm{BB}_{2}$ & LEFSKSMFNHIYRSHFVS \\
\hline $\mathrm{BB}_{3}$ & RLEFSESLFNHLYHSHFIT \\
\hline & YWLLY IYDYRLVNSENWI \\
\hline & VQAFHDRWSFQHF \\
\hline & IQSFHDRFSFNL \\
\hline & YHVFHFFPYIQQ \\
\hline & IHVYHY \\
\hline & \\
\hline
\end{tabular}

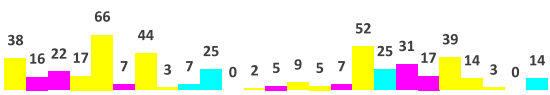

\section{C}

DOR

KOR

MOR

NOP

NPBW1

NPBW2

FPR1

FPR2

FPR3

MLNR

GHSR

$\mathrm{MC} 1$

MC2

MC3

MC 4

MC5

GNRHR

GAL1

GAL2

GAL3

NPSR1

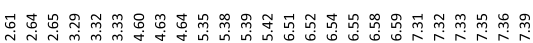

QKYLDYMAVDTKVIHFVWTVVALHI QVYIDYIGGDMKVIHFIEAALSYYI QNY IDYMATELKVI HYVKAQTVWH I QDIIDYAGSGFAIVQFVQGAVALRT NDFVDQFFAWSRTYHSTALVIASYT NEHLDHFFAFSRTFHASALVISSYT FRKFVDVRVLRGRYQVAATIGIVDS LSMHVDVFLLRGRFQVAGTIDIVNS RSVHIDNFWAFLHYEIGMAILVINS DRLLGEFLVAVMVFHGRYISQYNIL DRLQSEILVLMVSFHGRFSSQYNLF EVIDTCIYDFAMLFFHLIVIFKFNL LIDFVVSHLLMFFVHVMTYMSFQG EMIDICISEMAMLFFHLIIYTAFNL VIDICISDMTMLFFHLYIFMSFNL TIDICISEMAMLFFHLMLFMSFNL DWSKLQIFQYNTYYLGYWSDPNHF QVYHFTVHQKYVTHHIHAESFLRIH QIYHIFYYYRMDTHHLIVWTYARIH QIYHIYYYYRLDTHHLIEWTYARLH TNWRQVTIFWYMVYFFDDNRFYSVQ

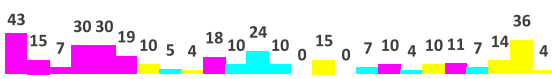

\section{D}

UT ITYFDFVAMHYLLFWWQAQARINYT

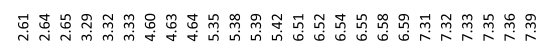
MCH1 MQLTDAVYALFTQYYLQQLFVYYNI MCH2 LQWTDTVYSVYTLYHIQNLFYVYYI SST1 LSTLDAIFSLFVTFYVQNVDATSQV SST2 LQVMDGIYAYFITFYFNSVLKGFDV SST3 LQNMDGVFSRFITFYLNNVFFGYFV SST4 VSALDGIFASFVTFYVQNLDATNHL SST5 LQNMDGLFAGFITFFVNNLSAGYFV

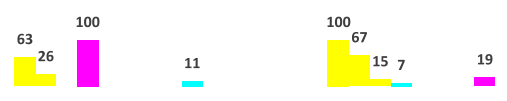

E

PAR1 KYYTFYLKEAFSSTNLLHYAYFYLV PAR2 KYHIFYLVKMYFLSNLLHYVYAYIL PAR3 KYHTEYFLKQYFLSNILHHLYFYLL PAR4 RYHTLYLQRWAFLSNLLHYLYGYVL

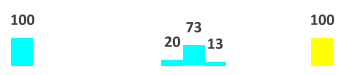

Fig. 2. Alignment of binding site residues for human class A peptide GPCRs. (A) GPCRs binding peptides with the C-terminal free carboxyl group pointing to the helical cavity. (B) GPCRs binding peptides with the C-terminal amidated group pointing to the helical cavity. (C) GPCRs binding peptides with the N-terminus pointing to the helical cavity. (D) GPCRs binding the cyclic peptides. (E) PAR receptors. Positively charged, negatively charged, and amide-containing residues are in cyan, purple, and yellow, respectively. Receptors co-crystalized with a peptide and synthetic ligands are in gray. Residues forming direct interactions with peptides are in bold. APLNR, apelin receptor; $\mathrm{AT}_{1}, \mathrm{AT}_{2}$, angiotensin receptors; $\mathrm{B}_{1}, \mathrm{~B}_{2}$, bradykinin receptors; $\mathrm{BB}_{1}, \mathrm{BB}_{2}, \mathrm{BB}_{3}$, bombesin receptors; C3a, C5a 1 , C5a $\mathrm{a}_{2}$, complement peptide receptors; CCK1, CCK2, cholecystokinin receptors; DOR, KOR, MOR, NOP, opioid receptors; $\mathrm{ET}_{\mathrm{A}}, \mathrm{ET}_{\mathrm{B}}$, endothelin receptors; FPR1, FPR2, FPR3, N-formyl peptide receptors; GAL1, GAL2, GAL3, galanin receptors; GHSR, ghrelin receptor; GNRHR, gonadotropin-releasing hormone receptor; KISS1R, kisspeptin receptor; MC1, MC2, MC3, MC4, MC5, melanocyte-stimulating 


\section{GPCRs Binding Peptides with the C-Terminal Free Carboxyl Group Interacting with the Helical Cavity}

The receptors binding angiotensin, apelin, complement $\mathrm{C}$ fragment, endothelin, neurotensin, bradykinin, and relaxin peptides are grouped together (Fig. 2A). From the alignment of the peptide binding site residues, we highlight positively charged residues at positions 4.64 (or placed within the second extracelular loop 2), 5.42, and 6.55 with a degree of conservation $(67 \%, 46 \%$, and $41 \%$, respectively).

$\mathrm{AT}_{2}, \mathrm{APLNR}, \mathrm{ET}_{\mathrm{B}}, \mathrm{NTS}_{1}$, and $\mathrm{C5a}_{1}$ have been crystallized in complex with a peptide, providing direct information about peptide-receptor interactions (White et al., 2012; Shihoya et al., 2016; Ma et al., 2017; Asada et al., 2018; Liu et al., 2018). Arginine at position 4.64 forms polar interactions with the backbone of angiotensin, apelin, and PMX53 in $\mathrm{AT}_{2}$, APLNR, and $\mathrm{C}^{2} \mathrm{a}_{1}$, respectively (Fig. 1). Lysine at position 5.42 forms a salt bridge with the free carboxyl group of angiotensin in $\mathrm{AT}_{2}$. Arginine at this position in $\mathrm{C}^{2} \mathrm{a}_{1}$ is $4.3 \AA$ away from the backbone of PMX53. Lysine or arginine at position 6.55 forms a salt bridge with the C-terminal carboxyl group of apelin and endothelin in APLNR and $\mathrm{ET}_{\mathrm{B}}$, respectively (Fig. 1). In the case of $\mathrm{NTS}_{1}$, residue 6.55 is at a distance of $3.8 \AA$ from the $\mathrm{C}$-terminal carboxyl group of neurotensin and, instead, arginine 6.54 forms a salt bridge with the terminal group of the peptide. Mutation of the charged residues in these three conserved positions reduces the peptide activity at $\mathrm{AT}_{2}, \mathrm{APLNR}, \mathrm{ET}_{\mathrm{B}}, \mathrm{NTS}_{1}$, and $\mathrm{C} \mathrm{a}_{1}$ (Labbe-Jullie et al., 1998; Higginbottom et al., 2005; Shihoya et al., 2016; Ma et al., 2017; Asada et al., 2018).

The two relaxin family peptide receptors, namely relaxin family peptides 3 and 4 (RXFP3 and RXFP4), have a positively charged residue in position 5.42, whereas the other two receptors, RFXP1 and RFXP2, in position 6.55. Mutation of the positively charged residue in these positions in RXFP3 and RXFP1 decreases peptide activity (Hu et al., 2016; Wong et al., 2018). Unlike other peptides of this group, the relaxin peptides are composed of two chains $A$ and B linked with three disulphide bonds (Table 2). The C-terminus of chain B of H3 relaxin carrying the peptide activity (Patil et al., 2017) is predicted to interact with the positively charged residue at position 5.42 in RXFP3 (Wong et al., 2018). In the bradykinin receptors $\left(\mathrm{B}_{1}\right.$ and $\left.\mathrm{B}_{2}\right)$, arginine at position 4.64 is conserved; however, no information on its importance in peptide binding is available in the literature.

\section{GPCRs Binding Peptides with the C-Terminal Amidated Carboxyl Group Interacting with the Helical Cavity}

Amidation of the C-terminal carboxyl group in a large number of regulatory peptides is important for biologic

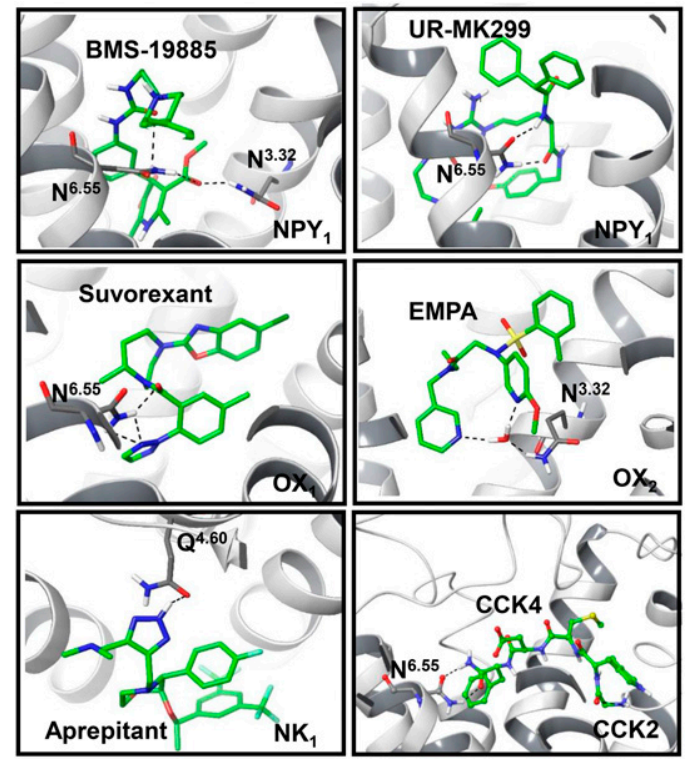

Fig. 3. Ligand binding sites of peptide GPCRs. Nonpeptide antagonist interactions with residues at positions 3.32 .4 .60 , and/or 6.55 in the crystal structures of $\mathrm{NPY}_{1}, \mathrm{OX}_{1}, \mathrm{OX}_{2}$, and $\mathrm{NK}_{1}$. Validated homology model of the CCK2 receptor complexed with the CCK4 peptide (Langer et al., 2005). The antagonists, the peptide CCK4, and the receptors are labeled and only the amide-containing residue is shown. Hydrogen bonding is in black-dashed lines.

activity (Eipper et al., 1992). This group of peptides includes cholecystokinin, gastrin, orexin, neuropeptide Y, prolactinreleasing peptide, pyroglutamylated RFamide peptide, neuropeptide FF, kisspeptin, vasopressin, oxytocin, bombesin, gastrin-releasing peptide, neuromedin $\mathrm{B}$, neuromedin $\mathrm{U}$, substance $\mathrm{P}$, neurokinin, and thyrotropin-releasing hormone. The receptors binding these peptides are grouped together and the alignment of binding-site residues highlights three notably conserved asparagine or glutamine at positions 3.32 , 4.60 , and 6.55 , with the conservation score of $66 \%, 44 \%$, and $52 \%$, respectively (Fig. 2B).

Currently, there is no crystal structure of a GPCR bound to an amidated peptide demonstrating direct interactions between the peptide $\mathrm{C}$-terminal amidated group and the receptor. However, the crystal structures of the neuropeptide $\mathrm{Y} 1\left(\mathrm{NPY}_{1}\right)$, orexin $\left(\mathrm{OX}_{1}\right.$ and $\left.\mathrm{OX}_{2}\right)$ and neurokinin $\left(\mathrm{NK}_{1}\right)$ receptors are available in complex with orthosteric nonpeptide ligands (Fig. 3), guiding thoughts on hydrophilic interactions between a peptide and the receptor helical bundle.

The NPY 1 crystal structure is obtained in complex with two synthetic antagonists, BMS-19885 and UR-MK299 (Yang et al., 2018). The carbonyl of BMS-19885 ester group forms H-bonding with glutamine and asparagine at positions 3.32 and 6.55 (Fig. 3). The peptide bond-like moiety of UR-MK299 is engaged in two acceptor- and donor- hydrogen bonds with residue

hormone receptors; MCH1, MCH2, melanin-concentrating hormone; MLNR, motilin receptor; NK1, NK2, NK3, neurokinin/tachykinin receptors; NMU1, NMU2, neuromedin-U receptors; NPBW1, NPBW2, neuropeptide B/W receptors; NPFF1, NPFF2, neuropeptide FF receptor; NPSR1, neuropeptide S receptor; $\mathrm{NPY}_{1}, \mathrm{NPY}_{2}, \mathrm{NPY}_{4}, \mathrm{NPY}_{5}$, neuropeptide Y receptors; NTS1, NTS2, neurotensin receptors; $\mathrm{OX}_{1}, \mathrm{OX}_{2}$, orexin receptors; OT, oxytocin receptor; PAR1, PAR2, PAR3, PAR4, PAR5, proteinase-activated receptors; PrRP, prolactin-releasing peptide receptor; QRFP, pyroglutamylated RFamide peptide receptor; RXFP1, RXFP2, RXFP3, RXFP4, relaxin receptors; SST1, SST2, SST3, SST4, SST5, somatostatin receptors; TRH1, thyrotropinreleasing hormone receptor; $\mathrm{V}_{1 \mathrm{~A}}, \mathrm{~V}_{1 \mathrm{~B}}, \mathrm{~V}_{2}$, vasopressin receptors; UT, urotensin receptor. Conservation score (\%) for each residue position calculated from the analysis of receptor orthologs (bovine, chimpanzee, guinea pig, human, mouse, rabbit, and rat) is shown at the bottom of each binding site residue alignment. The conservation score and the corresponded bar are shown for the most conserved positively charged (cyan), negatively charged (purple) or amide-containing residues (yellow). 
6.55 (Fig. 3). In mutagenesis studies, residues at positions 3.32 and 6.55 are predicted to be in contact with the peptide C-terminus and important for receptor activation (Sautel et al., 1996; Kaiser et al., 2015). Structurally, UR-MK299 imitates the C-terminal Arg and Tyr residues of the natural peptide, and its binding helps to model the binding mode of the peptide in $\mathrm{NPY}_{1}$ (Yang et al., 2018). Furthermore, a very recent study employing mutagenesis and synthesis of peptide analogs with the modified C-terminal amide group has suggested that the C-terminal amide group forms interactions with asparagine 6.55 (Xu et al., 2018).

The crystal structures of the orexin receptors are also available in complex with three synthetic antagonists, suvorexant, SB-674042, and EMPA (Yin et al., 2015, 2016; Suno et al., 2018). The tertiary amide carbonyl group of suvorexant and SB-674042 forms a hydrogen bond with asparagine at position 6.55 in $\mathrm{OX}_{1}$ and $\mathrm{OX}_{2}$ (Fig. 3, shown for Suvorexant only). This functional group of the antagonists mimics the peptide amide group, suggesting also a potential interaction with this residue either through the backbone or the amidated peptide C-terminus. Suvorexant and SB-674042 are in very close proximity to glutamine at position 3.32 (3.3 ̊), whereas EMPA forms a water-mediated contact with this residue (Suno et al., 2018) (Fig. 3). Although the role of asparagine 6.55 has not yet been validated in mutagenesis, mutation of glutamine at position 3.32 reduces the functional activity of the orexin peptides (Malherbe et al., 2010).

Residues 3.32 and 6.55 are also important in vasopressin binding to the vasopressin $\left(\mathrm{V}_{1 \mathrm{~A}}\right)$ receptor (Mouillac et al., 1995; Chini and Fanelli, 2000). In the case of the cholecystokinin receptors (CCK1 and CCK2), receptor mutagenesis and structure-affinity studies of modified CCK analogs suggest that asparagine 6.55 forms hydrogen bonds with the amidated carboxyl group of the peptide C-terminus (Fig. 3) (Gigoux et al., 1999; Galés et al., 2003; Langer et al., 2005).

The receptors binding the $\mathrm{RF}$-amide peptides, including neuropeptide $\mathrm{Y}$, prolactin-releasing peptide, pyroglutamylated peptide, neuropeptide FF, and kisspeptin, have conserved glutamine 3.32. However, apart from the NPY receptors, the role of this residue in the other $\mathrm{RF}$-amide receptors has not been established yet by mutagenesis. Another conserved residue in the RF-amide receptors is aspartate 6.59; mutation of this residue significantly attenuates peptide activity (Findeisen et al., 2011). From functional and modeling studies, it has been suggested that aspartate 6.59 interacts with the arginine of the peptide $\mathrm{RF}$-amide motif (Rathmann et al., 2012).

Mutagenesis studies of the bombesin receptors $\left(\mathrm{BB}_{2}\right.$ and $\mathrm{BB}_{3}$ ) indicate the importance of asparagine or arginine 3.32 for bombesin binding (Akeson et al., 1997; Nakamura et al., 2016). Mutation of tyrosine at position 6.55 in $\mathrm{BB}_{2}$ is critical for the activity of the peptide (Lin et al., 2000). Within the bombesin family, an additional three polar residues, at positions 2.61, 6.51, and 7.39, are conserved and critical for peptide binding (Donohue et al., 1999; Lin et al., 2000).

Glutamine 3.32 has not been mutated yet in the thyrotropinreleasing hormone receptor (TRH1). Mutations of other polar residues at positions $3.37,6.52$, and 7.39 significantly reduce the binding of thyrotropin-releasing hormone, suggesting direct interactions with the backbone of the peptide (Engel and Gershengorn, 2007).

In the neuromedin U receptors (NMU1 and NMU2), mutation of arginine 6.55 reduces peptide binding (Kawai et al., 2014). In addition, the importance of glutamates at positions 2.61 and 3.33 for the interaction with the peptide C-terminus has been shown in mutagenesis (Kawai et al., 2014).

The neurokinin receptors $\left(\mathrm{NK}_{1}, \mathrm{NK}_{2}\right.$, and $\left.\mathrm{NK}_{3}\right)$ do not have polar residues at positions 3.32 and 6.55 . However, the amidecontaining residue at position 4.60 , which is conserved within the subfamily, forms a hydrogen bond with the antagonists aprepitant (Fig. 2), CP-99,994, and netupitant in the $\mathrm{NK}_{1}$ crystal structure complexes (Yin et al., 2018; Schoppe et al., 2019) and has been predicted to bind to the neurokinin C-terminus according to mutagenesis and modeling studies (Lundstrom et al., 1997).

\section{GPCRs Binding Peptides with the N-Terminal End Pointing to the Helical Bundle}

Peptides having an $\mathrm{N}$-terminal end important for activity include opioid peptides, neuropeptides B/W, neuropeptide $\mathrm{S}$, N-formyl peptide, adrenocorticotropin, melanocortins, motilin, ghrelin, gonadotropin-releasing hormone, and galanin (Table 2). The sequence alignment of the binding site residues (Fig. 2C) identifies negatively charged residues in helix 2 at position 2.61 or in helix 3 either at positions $3.29,3.32$, or 3.33 in a large number of the receptors binding these peptides, with conservation scores of $43 \%, 30 \%, 30 \%$, and $19 \%$, respectively.

The crystal structures of the DOR and MOR receptors bound to a bifunctional peptide, DIPP-NH2, and the peptide agonist DAMGO, respectively, have been determined (Fenalti et al., 2015; Koehl et al., 2018). The N-terminus of both the peptides binds in a similar way, with the ammonium group forming a salt bridge with the aspartate at position 3.32 (Fig. 1). This interaction is conserved with opioid-like compounds as observed in their crystal complexes with the opioid receptors (Wu et al., 2017). Mutation of this residue is critical for the activity of endorphins and opioid-like compounds (Surratt et al., 1994; Li et al., 1999).

The importance of a negatively charged residue at position 3.32 for the receptors binding neuropeptides $\mathrm{B} / \mathrm{W}$ (NPBW1 and NPBW2) is unknown. Mutagenesis of aspartate or glutamate at position 3.33 in the FPR, motilin receptor (MLNR), and gonadotropin-releasing hormone receptors shows the significance of this residue for the binding of the N-formyl peptide, motilin, and ghrelin, respectively (Feighner et al., 1998; Mills et al., 2000; Xu et al., 2005). Binding studies of various analogs of the $\mathrm{N}$-formyl peptide and motilin suggest that the $\mathrm{N}$-terminal formyl-amide or the ammonium group interact with negatively charged aspartate or glutamate (Mills et al., 2000; Xu et al., 2005).

The importance of the negative charge at position 3.29 in the melanocortin receptors (MC1 and MC4) for the binding and potency of the melanocortin peptides is demonstrated in mutagenesis studies (Yang et al., 1997; Haskell-Luevano et al., 2001). However, it is not clear whether the N-terminal group or arginine of the critical phenylalanine-argininetryptophan (FRW) motif bind to the residue. Within the five melanocortin receptor subtypes, there are two other negatively charged residues, at positions 2.61 and 4.64 . While residue 4.64 does not substantially change the potency of the peptide, residue 2.61 has a profound effect on peptide binding (Yang et al., 1997; Haskell-Luevano et al., 2001). 
The receptors binding gonadotropin-releasing hormone, galanin, and neuropeptide $\mathrm{S}$ do not have a negatively charged residue in helices 2 and 3. However, there are negatively charged residues in other helices that are known to be important for the peptide activity. Thus, aspartate at position 2.61 is critical for peptide binding and signaling in the gonadotropin-releasing hormone receptor (GNRHR) (Hoffmann et al., 2000; Flanagan et al., 2000). In the galanin receptor (GAL1), mutagenesis and galanin SAR studies suggest that the ligand ammonium group binds to glutamate 6.59 (Kask et al., 1996; Church et al., 2002). The role of other negatively charged residues in position 5.39 in GAL2 and GAL3 and 6.55 and 6.58 in the neuropeptide S receptor (NPSR1) is unknown.

Over 20 GPCRs are known to bind chemokines. Because chemokines are classified as small proteins $(8-10 \mathrm{kDa})$, these receptors belong to the protein-bound GPCRs. As mentioned previously, several crystal structures of the chemokine receptors are available bound to short peptides whose $\mathrm{N}$-terminus points inside the helical bundle. Following the analysis of the receptor binding-site residues performed here, the negatively charged residues at positions $2.63,6.58,7.32$, and 7.39 have a level of conservation among the chemokine receptors. Direct interactions with some of these residues are observed in the crystal structures of the chemokine receptors in complex with peptide and nonpeptide ligands (Tan et al., 2013; Wu et al., 2017). Thus, in the crystal structure of the CXCR4 receptor bound with a viral chemokine antagonist, the peptide $\mathrm{N}$-terminal ammonium group forms a salt bridge with residue 2.63 (Qin et al., 2015). For a large peptide, like a chemokine, it is especially true that many binding factors, including steric and electrostatic interactions of various peptide residues, contribute together to peptide activity, thus the binding of the terminal ammonium group to a counterpart residue in the binding site might not be crucial.

\section{GPCRs Binding Cyclic Peptides with a Cyclic Part Important for Activity and the PAR Receptors}

The receptors binding urotensin, melanin-concentrating hormone, and somatostatin form a group with a conserved negatively charged residue at position 3.32 and a conserved amide-based residue at position 6.55 , with $100 \%$ conservation in orthologs (Fig. 2D). Residue 3.32 is known to be important for peptide binding (Strnad and Hadcock, 1995; Macdonald et al., 2000; Sainsily et al., 2013). From mutated peptide analog studies, it appears that the positively charged residue within the cyclic part of the peptide forms polar interactions with aspartate 3.32 (Audinot et al., 2001; Labarrere et al., 2003; Martin-Gago et al., 2013). The importance of residue 6.55 is demonstrated in the urotensin receptor (Holleran et al., 2009). Unlike other peptides with the C-terminal free carboxyl group, this group is not important for urotensin binding, as its amidation does not affect peptide activity (Labarrere et al., 2003; Merlino et al., 2013). In contrast, the cyclic part of these peptides conveys the activity (Audinot et al., 2001; Labarrere et al., 2003; Martin-Gago et al., 2013).

In the case of the PAR receptors, there are conserved charged residues at positions 2.61 and 4.64 and the asparagine at position 6.52 (Fig. 2E). Position 4.64 is similar to the first group. While the lysine at position 2.61 forms direct interactions with the synthetic ligand AZ8838 in the crystal structure of PAR2 (Cheng et al., 2017), positions 4.64 and 6.52 have not been yet explored. The importance of the extracellular loops in peptide binding has been examined in mutagenesis studies (Gerszten et al., 1994); however, the role of residues in the helical cavity needs further investigation.

\section{Concluding Remarks}

In this review, using earlier peptide SAR studies combined with alignment of binding site residues derived from the recent GPCR-peptide complex crystal structures, we divided the peptide GPCRs of class A into three major groups. In particular, we used the 25 residues of the GPCR helical bundle to characterize the hydrophilic properties of the receptor binding cavity.

The first group consists of the receptors that bind the free C-terminal carboxyl group of peptides inside the helical bundle. These receptors have several relatively conserved, positively charged residues at positions 4.64, 5.42, and 6.55. From the available crystal structures, these residues form polar interactions either with the C-terminal free carboxyl group or the peptide backbone. A recognition residue in a receptor for the peptide C-terminal carboxylate is not fully preserved, and a positively charged residue at other nonconserved positions could contribute to peptide binding. Thus, the interaction with the terminal carboxylate involves arginine at position 6.54 in $\mathrm{NTS}_{1}$ and lysine at positions 3.33 and 5.38 in $\mathrm{ET}_{\mathrm{B}}$.

The second large group involves the receptors binding amidated peptides. Interestingly, these receptors have relatively conserved asparagine or glutamine at positions $3.32,4.60$, and 6.55. The analysis of the peptide SAR studies combined with receptor mutagenesis and the available crystal structures of the receptors in complex with synthetic antagonists suggests that the peptide terminal amide forms interactions with a counterpart amide group of glutamine or asparagine at one of these positions. In contrast to the group of the receptors binding peptides with the terminal free carboxyl group, this group of the receptors does not have conserved polar residues at positions 4.64 and 5.42 but has conserved asparagine or glutamine at position 6.55 , instead of arginine or lysine. Residue 6.55 appears to be critical in peptide binding and could contribute to the differentiation of the C-terminus property for several receptors of these two groups.

The third group includes the receptors binding peptides with the $\mathrm{N}$-terminus interacting with the helical bundle. Our analysis identifies a regular presence of a negatively charged residue at positions $2.61,3.29,3.32$, and 3.33 . The crystal structures of the opioid receptors bound to peptides show that the ionic interaction between the peptide N-terminal ammonium group and residue 3.32. Analysis of available SAR and mutagenesis data for several receptors of this group suggests the presence of ionic interaction between the peptide terminal ammonium group and a negatively charged residue of the receptor. In comparison with the first two groups, these receptors have a few positively charged and amide-containing residues in the binding cavity. Unlike the receptors binding amidated peptides, several receptors have aspartate at position 3.32 instead of glutamine.

The receptors binding the cyclic peptides with the cyclic part being important for activity have conserved aspartate and 
glutamine/asparagine at positions 3.32 and 6.55, respectively. The importance of these residues is shown in mutagenesis for several receptors of this group. The PAR receptors form a separate group with conserved polar residues at positions $2.61,4.64$, and 6.52 .

Comparison of the conservation score for the hydrophilic residues in the alignment of the binding site residues in the three major receptor groups shows a clear pattern in the conserved residue preference in the receptor group. In particular, the highest conservation score in the first group is for the positively charged residues, in the second group, for the amide-containing residues, and in the third group is for the negatively charged residues. Thus, the proposed grouping of the receptors on the basis of the peptide SAR data are justified from the sequence analyses of receptor orthologs.

The recent reporting of crystal structures of GPCRs bound to peptides allows assessment of the structural diversity of peptide binding for the first time. Furthermore, the structural data facilitates interpretation of peptide SAR studies and allows extrapolation of findings to related GPCRs. Thus, our polar residue analysis allows a grouping of the peptide receptors that highlights conserved residues important for peptide binding. Despite a large heterogeneity in possible binding modes of peptides within GPCRs, some level of generalization of peptide binding can be established through the analysis of the peptide terminal-end binding to the transmembrane helical cavity of GPCRs.

Further understanding of peptide-GPCR recognition has important implications for the design of peptides and peptidelike molecules as new pharmacological tools and medicines. From the conservation of a specific type of hydrophilic residue in a receptor, the binding orientation of peptides in the helical bundle could be identified, and therefore the important part of peptides for activity could be determined. This, in turn, provides a rationale for peptide modification. This knowledge can also facilitate peptide receptor deorphanization. Although 47 mammalian GPCRs were only analyzed here, studies could be expanded to neuropeptide GPCRs of parasitic nematodes and insects to facilitate a better understanding of peptide binding sites and improve design of GPCR-targeting agrochemicals.

\section{Acknowledgments}

We thank Dr. Karl Malcom, Dr. Antonella Ciancetta, and reviewers for critical review of the manuscript.

\section{Authorship Contributions}

Participated in research design: Tikhonova, Fourmy. Performed data analysis: Tikhonova, Gigoux, Fourmy(pe).

Wrote or contributed to the writing of the manuscript: Tikhonova.

\section{References}

Akeson M, Sainz E, Mantey SA, Jensen RT, and Battey JF (1997) Identification of four amino acids in the gastrin-releasing peptide receptor that are required for high affinity agonist binding. J Biol Chem 272:17405-17409.

Ammoun S, Holmqvist T, Shariatmadari R, Oonk HB, Detheux M, Parmentier M, Akerman KE, and Kukkonen JP (2003) Distinct recognition of OX1 and OX2 receptors by orexin peptides. J Pharmacol Exp Ther 305:507-514.

Archer-Lahlou E, Tikhonova I, Escrieut C, Dufresne M, Seva C, Pradayrol L, Moroder L, Maigret B, and Fourmy D (2005) Modeled structure of a G-proteincoupled receptor: the cholecystokinin-1 receptor. J Med Chem 48:180-191.

Asada H, Horita S, Hirata K, Shiroishi M, Shiimura Y, Iwanari H, Hamakubo T, Shimamura T, Nomura N, Kusano-Arai O, et al. (2018) Crystal structure of the human angiotensin II type 2 receptor bound to an angiotensin II analog. Nat Struct Mol Biol 25:570-576.

Audinot V, Beauverger P, Lahaye C, Suply T, Rodriguez M, Ouvry C, Lamamy V, Imbert J, Rique H, Nahon JL, et al. (2001) Structure-activity relationship studies of melanin-concentrating hormone (MCH)-related peptide ligands at SLC-1, the human MCH receptor. J Biol Chem 276:13554-13562.
Ballesteros JA and Weinstein $\mathrm{H}$ (1995) Modeling transmembrane helix contacts in GPCR. Biophys $J$ 68:A446.

Barran PE, Roeske RW, Pawson AJ, Sellar R, Bowers MT, Morgan K, Lu ZL, Tsuda M, Kusakabe T, and Millar RP (2005) Evolution of constrained gonadotropinreleasing hormone ligand conformation and receptor selectivity. J Biol Chem 280:38569-38575

Bathgate RA, Oh MH, Ling WJ, Kaas Q, Hossain MA, Gooley PR, and Rosengren KJ (2013) Elucidation of relaxin-3 binding interactions in the extracellular loops of RXFP3. Front Endocrinol (Lausanne) 4:13.

Black JW and Kalindjian SB (2002) Gastrin agonists and antagonists. Pharmaco Toxicol 91:275-281.

Boublik JH, Scott NA, Brown MR, and Rivier JE (1989) Synthesis and hypertensive activity of neuropeptide $\mathrm{Y}$ fragments and analogues with modified N- or C-termini or D-substitutions. J Med Chem 32:597-601.

Boyle RG, Downham R, Ganguly T, Humphries J, Smith J, and Travers S (2005) Structure-activity studies on prolactin-releasing peptide (PrRP). Analogues of PrRP-(19-31)-peptide. J Pept Sci 11:161-165.

Brighton PJ, Szekeres PG, and Willars GB (2004) Neuromedin U and its receptors: structure, function, and physiological roles. Pharmacol Rev 56:231-248.

Burg JS, Ingram JR, Venkatakrishnan AJ, Jude KM, Dukkipati A, Feinberg EN, Angelini A, Waghray D, Dror RO, Ploegh HL, et al. (2015) Structural biology. Structural basis for chemokine recognition and activation of a viral G proteincoupled receptor. Science 347:1113-1117.

Chang JK, Sievertsson H, Currie B, Folkers K, and Bowers C (1971) Synthesis of analogs of the thyrotropin-releasing hormone and structure-activity relationship. J Med Chem 14:484-487.

Charron CL, Hou J, McFarland MS, Dhanvantari S, Kovacs MS, and Luyt LG (2017) Structure-activity study of ghrelin(1-8) resulting in high affinity fluorine-bearing ligands for the ghrelin receptor. J Med Chem 60:7256-7266.

Chavkin C and Goldstein A (1981) Specific receptor for the opioid peptide dynorphin: structure--activity relationships. Proc Natl Acad Sci USA 78:6543-6547.

Cheng RKY, Fiez-Vandal C, Schlenker O, Edman K, Aggeler B, Brown DG, Brown GA, Cooke RM, Dumelin CE, Doré AS, et al. (2017) Structural insight into allosteric modulation of protease-activated receptor 2. Nature 545:112-115.

Chini B and Fanelli F (2000) Molecular basis of ligand binding and receptor activation in the oxytocin and vasopressin receptor family. Exp Physiol 85:59S-66S.

Church WB, Jones KA, Kuiper DA, Shine J, and Iismaa TP (2002) Molecular modelling and site-directed mutagenesis of human GALR1 galanin receptor defines determinants of receptor subtype specificity. Protein Eng 15:313-323.

Couture R, Fournier A, Magnan J, St-Pierre S, and Regoli D (1979) Structure-activity studies on substance P. Can J Physiol Pharmacol 57:1427-1436.

Darker JG, Porter RA, Eggleston DS, Smart D, Brough SJ, Sabido-David C, and Jerman JC (2001) Structure-activity analysis of truncated orexin-A analogues at the orexin-1 receptor. Bioorg Med Chem Lett 11:737-740.

Donohue PJ, Sainz E, Akeson M, Kroog GS, Mantey SA, Battey JF, Jensen RT, and Northup JK (1999) An aspartate residue at the extracellular boundary of TMII and an arginine residue in TMVII of the gastrin-releasing peptide receptor interact to facilitate heterotrimeric G protein coupling. Biochemistry 38:9366-9372.

Dufresne M, Seva C, and Fourmy D (2006) Cholecystokinin and gastrin receptors. Physiol Rev 86:805-847.

Eipper BA, Stoffers DA, and Mains RE (1992) The biosynthesis of neuropeptides: peptide alpha-amidation. Annu Rev Neurosci 15:57-85.

Engel S and Gershengorn MC (2007) Thyrotropin-releasing hormone and its receptors--a hypothesis for binding and receptor activation. Pharmacol Ther 113 410-419.

Feighner SD, Howard AD, Prendergast K, Palyha OC, Hreniuk DL, Nargund R, Underwood D, Tata JR, Dean DC, Tan CP, et al. (1998) Structural requirements for the activation of the human growth hormone secretagogue receptor by peptide and nonpeptide secretagogues. Mol Endocrinol 12:137-145.

Fenalti G, Zatsepin NA, Betti C, Giguere P, Han GW, Ishchenko A, Liu W, Guillemyn K, Zhang H, James D, et al. (2015) Structural basis for bifunctional peptide recognition at human $\delta$-opioid receptor. Nat Struct Mol Biol 22:265-268.

Findeisen M, Rathmann D, and Beck-Sickinger AG (2011) Structure-activity studies of RFamide peptides reveal subtype-selective activation of neuropeptide FF1 and FF2 receptors. ChemMedChem 6:1081-1093.

Flanagan CA, Rodic V, Konvicka K, Yuen T, Chi L, Rivier JE, Millar RP, Weinstein $\mathrm{H}$, and Sealfon SC (2000) Multiple interactions of the Asp(2.61(98)) side chain of the gonadotropin-releasing hormone receptor contribute differentially to ligand interaction. Biochemistry 39:8133-8141.

Galés C, Poirot M, Taillefer J, Maigret B, Martinez J, Moroder L, Escrieut C, Pradayrol L, Fourmy D, and Silvente-Poirot S (2003) Identification of tyrosine 189 and asparagine 358 of the cholecystokinin 2 receptor in direct interaction with the crucial C-terminal amide of cholecystokinin by molecular modeling, site-directed mutagenesis, and structure/affinity studies. Mol Pharmacol 63:973-982.

Ganjiwale AD, Rao GS, and Cowsik SM (2011) Molecular modeling of neurokinin B and tachykinin $\mathrm{NK}_{3}$ receptor complex. J Chem Inf Model 51:2932-2938.

Gerszten RE, Chen J, Ishii M, Ishii K, Wang L, Nanevicz T, Turck CW, Vu TK, and Coughlin SR (1994) Specificity of the thrombin receptor for agonist peptide is defined by its extracellular surface. Nature 368:648-651.

Gigoux V, Escrieut C, Fehrentz JA, Poirot S, Maigret B, Moroder L, Gully D, Martinez J, Vaysse N, and Fourmy D (1999) Arginine 336 and asparagine 333 of the human cholecystokinin-A receptor binding site interact with the penultimate aspartic acid and the C-terminal amide of cholecystokinin. J Biol Chem 274 20457-20464.

Gimpl G and Fahrenholz F (2001) The oxytocin receptor system: structure, function, and regulation. Physiol Rev 81:629-683.

Ha SN, Hey PJ, Ransom RW, Bock MG, Su DS, Murphy KL, Chang R, Chen TB, Pettibone D, and Hess JF (2006) Identification of the critical residues of bradykinin receptor B1 for interaction with the kinins guided by site-directed mutagenesis and molecular modeling. Biochemistry 45:14355-14361. 
Haskell-Luevano C, Cone RD, Monck EK, and Wan YP (2001) Structure activity studies of the melanocortin-4 receptor by in vitro mutagenesis: identification of agouti-related protein (AGRP), melanocortin agonist and synthetic peptide antagonist interaction determinants. Biochemistry 40:6164-6179.

Heifetz A, Barker O, Morris GB, Law RJ, Slack M, and Biggin PC (2013) Toward an understanding of agonist binding to human Orexin-1 and Orexin-2 receptors with G-protein-coupled receptor modeling and site-directed mutagenesis. Biochemistry 52:8246-8260

Higginbottom A, Cain SA, Woodruff TM, Proctor LM, Madala PK, Tyndall JD, Taylor SM, Fairlie DP, and Monk PN (2005) Comparative agonist/antagonist responses in mutant human C5a receptors define the ligand binding site. J Biol Chem 280 : 17831-17840.

Hoffmann SH, ter Laak T, Kühne R, Reiländer H, and Beckers T (2000) Residues within transmembrane helices 2 and 5 of the human gonadotropin-releasing hormone receptor contribute to agonist and antagonist binding. Mol Endocrinol 14: 1099-1115.

Holleran BJ, Domazet I, Beaulieu ME, Yan LP, Guillemette G, Lavigne P, Escher E, and Leduc $\mathrm{R}$ (2009) Identification of transmembrane domain 6 \& 7 residues that contribute to the binding pocket of the urotensin II receptor. Biochem Pharmacol 77:1374-1382.

Hu MJ, Wei D, Shao XX, Wang JH, Liu YL, Xu ZG, and Guo ZY (2017) Interaction mechanism of insulin-like peptide 5 with relaxin family peptide receptor 4 . Arch Biochem Biophys 619:27-34.

Hu X, Myhr C, Huang Z, Xiao J, Barnaeva E, Ho BA, Agoulnik IU, Ferrer M, Marugan JJ, Southall N, et al. (2016) Structural insights into the activation of human relaxin family peptide receptor 1 by small-molecule agonists. Biochemistry 55:1772-1783.

Jard S and Bockaert J (1975) Stimulus-response coupling in neurohypophysial peptide target cells. Physiol Rev 55:489-536.

Jarnagin K, Bhakta S, Zuppan P, Yee C, Ho T, Phan T, Tahilramani R, Pease JH, Miller A, and Freedman R (1996) Mutations in the B2 bradykinin receptor revea a different pattern of contacts for peptidic agonists and peptidic antagonists. J Biol Chem 271:28277-28286.

Jensen RT, Battey JF, Spindel ER, and Benya RV (2008) International Union of Pharmacology. LXVIII. Mammalian bombesin receptors: nomenclature, distribution, pharmacology, signaling, and functions in normal and disease states. Pharmacol Rev 60: $1-42$.

Jensen RT, Lemp GF, and Gardner JD (1982) Interactions of COOH-terminal fragments of cholecystokinin with receptors on dispersed acini from guinea pig pancreas. J Biol Chem 257:5554-5559.

Kaiser A, Müller P, Zellmann T, Scheidt HA, Thomas L, Bosse M, Meier R, Meiler J, Huster D, Beck-Sickinger AG, et al. (2015) Unwinding of the C-terminal residues of neuropeptide $\mathrm{Y}$ is critical for $\mathrm{Y}_{2}$ receptor binding and activation. Angew Chem Int Ed Engl 54:7446-7449.

Kanesaka M, Matsuda M, Hirano A, Tanaka K, Kanatani A, and Tokita S (2007) Development of a potent and selective GPR7 (NPBW1) agonist: a systematic structure-activity study of neuropeptide B. J Pept Sci 13:379-385.

Karnik SS (2000) Conformational theories on receptor activation from studies of the AT1 receptor, in Drugs, Enzymes and Receptors of the Renin-Angiotensin System: Celebrating a Century of Discovery (Husain A and Graham R eds) pp 117-130 Harwood Academic Publishers, Amsterdam.

Kask K, Berthold M, Kahl U, Nordvall G, and Bartfai T (1996) Delineation of the peptide binding site of the human galanin receptor. EMBO J 15:236-244.

Kawai T, Katayama Y, Guo L, Liu D, Suzuki T, Hayakawa K, Lee JM, Nagamine T, Hull JJ, Matsumoto S, et al. (2014) Identification of functionally important residues of the silkmoth pheromone biosynthesis-activating neuropeptide receptor, an insect ortholog of the vertebrate neuromedin $\mathrm{U}$ receptor. $J$ Biol Chem $\mathbf{2 8 9}$ 19150-19163.

Kleczkowska P and Lipkowski AW (2013) Neurotensin and neurotensin receptors characteristic, structure-activity relationship and pain modulation--a review. Eur $J$ Pharmacol 716:54-60.

Klos A, Wende E, Wareham KJ, and Monk PN (2013) International union of basic and clinical pharmacology. LXXXVII. Complement Peptide C5a, C4a and C3a Receptors. Pharmacol Rev 65:500-543.

Koehl A, Hu H, Maeda S, Zhang Y, Qu Q, Paggi JM, Latorraca NR, Hilger D, Dawson R, Matile H, et al. (2018) Structure of the $\mu$-opioid receptor- $\mathrm{G}_{\mathrm{i}}$ protein complex. Nature 558:547-552.

Kotani M, Detheux M, Vandenbogaerde A, Communi D, Vanderwinden JM, Le Poul E, Brézillon S, Tyldesley R, Suarez-Huerta N, Vandeput F, et al. (2001) The metastasis suppressor gene KiSS-1 encodes kisspeptins, the natural ligands of the orphan G protein-coupled receptor GPR54. J Biol Chem 276:34631-34636.

Labarrère $\mathrm{P}$, Chatenet $\mathrm{D}$, Leprince J, Marionneau C, Loirand G, Tonon MC, Dubessy C, Scalbert E, Pfeiffer B, Renard P, et al. (2003) Structure-activity relationships of human urotensin II and related analogues on rat aortic ring contraction. J Enzyme Inhib Med Chem 18:77-88.

Labbé-Jullié C, Barroso S, Nicolas-Etève D, Reversat JL, Botto JM, Mazella J, Bernassau JM, and Kitabgi P (1998) Mutagenesis and modeling of the neurotensin receptor NTR1. Identification of residues that are critical for binding SR 48692, a nonpeptide neurotensin antagonist. J Biol Chem 273:16351-16357.

Lang M, Söll RM, Dürrenberger F, Dautzenberg FM, and Beck-Sickinger AG (2004) Structure-activity studies of orexin a and orexin B at the human orexin 1 and orexin 2 receptors led to orexin 2 receptor selective and orexin 1 receptor preferring ligands. J Med Chem 47:1153-1160.

Lang R, Gundlach AL, Holmes FE, Hobson SA, Wynick D, Hökfelt T, and Kofler B (2015) Physiology, signaling, and pharmacology of galanin peptides and receptors: three decades of emerging diversity. Pharmacol Rev 67:118-175.

Langer I, Tikhonova IG, Travers MA, Archer-Lahlou E, Escrieut C, Maigret B, and Fourmy D (2005) Evidence that interspecies polymorphism in the human and rat cholecystokinin receptor-2 affects structure of the binding site for the endogenous agonist cholecystokinin. J Biol Chem 280:22198-22204.
Lau JL and Dunn MK (2018) Therapeutic peptides: historical perspectives, current development trends, and future directions. Bioorg Med Chem 26:2700-2707.

Li JG, Chen C, Yin J, Rice K, Zhang Y, Matecka D, de Riel JK, DesJarlais RL, and Liu-Chen LY (1999) ASP147 in the third transmembrane helix of the rat mu opioid receptor forms ion-pairing with morphine and naltrexone. Life Sci 65 $175-185$

Lin JT, Coy DH, Mantey SA, and Jensen RT (1995) Comparison of the peptide structural requirements for high affinity interaction with bombesin receptors. Eur J Pharmacol 294:55-69.

Lin Y, Jian X, Lin Z, Kroog GS, Mantey S, Jensen RT, Battey J, and Northup J (2000) Two amino acids in the sixth transmembrane segment of the mouse gastrinreleasing peptide receptor are important for receptor activation. J Pharmacol Exp Ther 294:1053-1062.

Liu H, Kim HR, Deepak RNVK, Wang L, Chung KY, Fan H, Wei Z, and Zhang C (2018) Orthosteric and allosteric action of the C5a receptor antagonists. Nat Struct Mol Biol 25:472-481.

Lundstrom K, Hawcock AB, Vargas A, Ward P, Thomas P, and Naylor A (1997) Effect of single point mutations of the human tachykinin NK1 receptor on antagonist affinity. Eur $J$ Pharmacol 337:73-81.

Ma Y, Yue Y, Ma Y, Zhang Q, Zhou Q, Song Y, Shen Y, Li X, Ma X, Li C, et al. (2017) Structural basis for apelin control of the human apelin receptor. Structure 25 858-866.e4.

Macdonald D, Murgolo N, Zhang R, Durkin JP, Yao X, Strader CD, and Graziano MP (2000) Molecular characterization of the melanin-concentrating hormone/receptor complex: identification of critical residues involved in binding and activation. $\mathrm{Mol}$ Pharmacol 58:217-225.

Malherbe P, Roche O, Marcuz A, Kratzeisen C, Wettstein JG, and Bissantz C (2010) Mapping the binding pocket of dual antagonist almorexant to human orexin 1 and orexin 2 receptors: comparison with the selective OX1 antagonist SB-674042 and the selective OX2 antagonist N-ethyl-2-[(6-methoxy-pyridin-3-yl)-(toluene-2sulfonyl)-amino]-N-pyridin-3-ylmethyl-acetamide (EMPA). Mol Pharmacol 78:81-93.

Martín-Gago P, Aragón E, Gomez-Caminals M, Fernández-Carneado J, Ramón R Martin-Malpartida P, Verdaguer X, López-Ruiz P, Colás B, Cortes MA, et al. (2013) Insights into structure-activity relationships of somatostatin analogs containing mesitylalanine. Molecules 18:14564-14584

Matsunaga TO, Castrucci AM, Hadley ME, and Hruby VJ (1989) Melanin concentrating hormone $(\mathrm{MCH})$ : synthesis and bioactivity studies of $\mathrm{MCH}$ fragment analogues. Peptides 10:349-354.

Merlino F, Di Maro S, Munaim Yousif A, Caraglia M, and Grieco P (2013) Urotensinii ligands: an overview from peptide to nonpeptide structures. J Amino Acids 2013 : 979016.

Mervic M, Moody TW, and Komoriya A (1991) A structure function study of C-terminal extensions of bombesin. Peptides 12:1149-1151.

Mills JS, Miettinen HM, Cummings D, and Jesaitis AJ (2000) Characterization of the binding site on the formyl peptide receptor using three receptor mutants and analogs of Met-Leu-Phe and Met-Met-Trp-Leu-Leu. J Biol Chem 275:39012-39017.

Mollison KW, Mandecki W, Zuiderweg ER, Fayer L, Fey TA, Krause RA, Conway RG, Miller L, Edalji RP, Shallcross MA, et al. (1989) Identification of receptor-binding residues in the inflammatory complement protein C5a by site-directed mutagenesis. Proc Natl Acad Sci USA 86:292-296.

Morley JS (1983) Chemistry of opioid peptides. Br Med Bull 39:5-10.

Morley JS, Tracy HJ, and Gregory RA (1965) Structure-function relationships in the active C-terminal tetrapeptide sequence of gastrin. Nature 207:1356-1359.

Mouillac B, Chini B, Balestre MN, Elands J, Trumpp-Kallmeyer S, Hoflack J, Hibert M, Jard S, and Barberis C (1995) The binding site of neuropeptide vasopressin V1a receptor. Evidence for a major localization within transmembrane regions. J Biol Chem 270:25771-25777.

Murza A, Parent A, Besserer-Offroy E, Tremblay H, Karadereye F, Beaudet N, Leduc R, Sarret P, and Marsault É (2012) Elucidation of the structure-activity relationships of apelin: influence of unnatural amino acids on binding, signaling, and plasma stability. ChemMedChem 7:318-325.

Nakamura T, Ramos-Álvarez I, Iordanskaia T, Moreno P, Mantey SA, and Jensen RT (2016) Molecular basis for high affinity and selectivity of peptide antagonist, Bantag-1, for the orphan BB3 receptor. Biochem Pharmacol 115:64-76.

Padula AM (2005) GnRH analogues--agonists and antagonists. Anim Reprod Sci 88: 115-126.

Patil NA, Rosengren KJ, Separovic F, Wade JD, Bathgate RAD, and Hossain MA (2017) Relaxin family peptides: structure-activity relationship studies. $\mathrm{Br} \mathrm{J}$ Pharmaco 174:950-961.

Poitras P, Gagnon D, and St-Pierre S (1992) N-terminal portion of motilin determines its biological activity. Biochem Biophys Res Commun 183:36-40.

Portoghese PS, Moe ST, and Takemori AE (1993) A selective delta 1 opioid receptor agonist derived from oxymorphone. Evidence for separate recognition sites for delta 1 opioid receptor agonists and antagonists. J Med Chem 36:2572-2574.

Portoghese PS, Sultana M, Nagase H, and Takemori AE (1988) Application of the message-address concept in the design of highly potent and selective non-peptide delta opioid receptor antagonists. $J$ Med Chem 31:281-282.

Prossnitz ER and Ye RD (1997) The N-formyl peptide receptor: a model for the study of chemoattractant receptor structure and function. Pharmacol Ther 74:73-102.

Qin L, Kufareva I, Holden LG, Wang C, Zheng Y, Zhao C, Fenalti G, Wu H, Han GW, Cherezov V, et al. (2015) Structural biology. Crystal structure of the chemokine receptor CXCR4 in complex with a viral chemokine. Science 347:1117-1122.

Rathmann D, Lindner D, DeLuca SH, Kaufmann KW, Meiler J, and Beck-Sickinger AG (2012) Ligand-mimicking receptor variant discloses binding and activation mode of prolactin-releasing peptide. $J$ Biol Chem 287:32181-32194.

Rhaleb NE, Drapeau G, Dion S, Jukic D, Rouissi N, and Regoli D (1990) Structureactivity studies on bradykinin and related peptides: agonists. $\mathrm{Br}$ J Pharmacol 99 $445-448$.

Rioux F, Park WK, and Regoli D (1975) Role of the C-terminal group for the biological activities of angiotensin. Can J Physiol Pharmacol 53:383-391. 
Robertson N, Rappas M, Doré AS, Brown J, Bottegoni G, Koglin M, Cansfield J, Jazayeri A, Cooke RM, and Marshall FH (2018) Structure of the complement C5a receptor bound to the extra-helical antagonist NDT9513727. Nature 553:111-114.

Roth AL, Marzola E, Rizzi A, Arduin M, Trapella C, Corti C, Vergura R, Martinelli P, Salvadori S, Regoli D, et al. (2006) Structure-activity studies on neuropeptide S: identification of the amino acid residues crucial for receptor activation. J Biol Chem 281:20809-20816.

Rovero P, Patacchini R, and Maggi CA (1990) Structure-activity studies on endothelin (16-21), the C-terminal hexapeptide of the endothelins, in the guinea-pig bronchus. Br J Pharmacol 101:232-234.

Sainsily X, Cabana J, Boulais PE, Holleran BJ, Escher E, Lavigne P, and Leduc R (2013) Identification of transmembrane domain $3,4 \& 5$ residues that contribute to the formation of the ligand-binding pocket of the urotensin-II receptor. Biochem Pharmacol 86:1584-1593.

Sautel M, Rudolf K, Wittneben H, Herzog H, Martinez R, Munoz M, Eberlein W, Engel W, Walker P, and Beck-Sickinger AG (1996) Neuropeptide Y and the nonpeptide antagonist BIBP 3226 share an overlapping binding site at the human Y1 receptor. Mol Pharmacol 50:285-292.

Schiöth HB, Muceniece R, Larsson M, and Wikberg JE (1997) The melanocortin 1, 3, 4 or 5 receptors do not have a binding epitope for ACTH beyond the sequence of alpha-MSH. J Endocrinol 155:73-78.

Schoppe J, Ehrenmann J, Klenk C, Rucktooa P, Schutz M, Dore AS, and Pluckthun A (2019) Crystal structures of the human neurokinin 1 receptor in complex with clinically used antagonists. Nat Commun 10:17.

Schwyzer R (1977) ACTH: a short introductory review. Ann N Y Acad Sci 297:3-26.

Shihoya W, Nishizawa T, Okuta A, Tani K, Dohmae N, Fujiyoshi Y, Nureki O, and Doi T (2016) Activation mechanism of endothelin $\mathrm{ET}_{\mathrm{B}}$ receptor by endothelin 1. Nature 537:363-368.

Strnad J and Hadcock JR (1995) Identification of a critical aspartate residue in transmembrane domain three necessary for the binding of somatostatin to the somatostatin receptor SSTR2. Biochem Biophys Res Commun 216:913-921.

Suno R, Kimura KT, Nakane T, Yamashita K, Wang J, Fujiwara T, Yamanaka Y, Im D, Horita S, Tsujimoto H, et al. (2018) Crystal structures of human orexin 2 receptor bound to the subtype-selective antagonist EMPA. Structure 26:7-19.e5.

Surratt CK, Johnson PS, Moriwaki A, Seidleck BK, Blaschak CJ, Wang JB, and Uhl GR (1994) -mu opiate receptor. Charged transmembrane domain amino acids are critical for agonist recognition and intrinsic activity. $J$ Biol Chem 269:20548-20553.

Tan Q, Zhu Y, Li J, Chen Z, Han GW, Kufareva I, Li T, Ma L, Fenalti G, Li J, et al. (2013) Structure of the CCR5 chemokine receptor-HIV entry inhibitor maraviroc complex. Science 341:1387-1390.

Vale W, Rivier J, Ling N, and Brown M (1978) Biologic and immunologic activities and applications of somatostatin analogs. Metabolism 27 (9 Suppl 1):1391-1401.
White JF, Noinaj N, Shibata Y, Love J, Kloss B, Xu F, Gvozdenovic-Jeremic J, Shah P, Shiloach J, Tate CG, et al. (2012) Structure of the agonist-bound neurotensin receptor. Nature 490:508-513.

Wong LLL, Scott DJ, Hossain MA, Kaas Q, Rosengren KJ, and Bathgate RAD (2018) Distinct but overlapping binding sites of agonist and antagonist at the relaxin family peptide 3 (RXFP3) receptor. J Biol Chem 293:15777-15789.

Wu B, Chien EY, Mol CD, Fenalti G, Liu W, Katritch V, Abagyan R, Brooun A, Wells P, Bi FC, et al. (2010) Structures of the CXCR4 chemokine GPCR with smallmolecule and cyclic peptide antagonists. Science 330:1066-1071.

Wu F, Song G, de Graaf C, and Stevens RC (2017) Structure and function of peptidebinding G protein-coupled receptors. J Mol Biol 429:2726-2745.

Xu B, Fällmar H, Boukharta L, Pruner J, Lundell I, Mohell N, Gutiérrez-de-Terán H, Aqvist J, and Larhammar D (2013) Mutagenesis and computational modeling of human G-protein-coupled receptor Y2 for neuropeptide Y and peptide YY. Biochemistry 52:7987-7998.

Xu B Vasile S, Østergaard S, Paulsson JF, Pruner J, Åqvist J, Wulff BS, Gutiérrez-de-Terán H, and Larhammar D (2018) Elucidation of the binding mode of the carboxyterminal region of peptide $\mathrm{YY}$ to the human $\mathrm{Y}_{2}$ receptor. Mol Pharmacol 93:323-334.

Xu L, Depoortere I, Vertongen P, Waelbroeck M, Robberecht P, and Peeters TL (2005) Motilin and erythromycin-A share a common binding site in the third transmembrane segment of the motilin receptor. Biochem Pharmacol 70:879-887.

Yang Y, Dickinson C, Haskell-Luevano C, and Gantz I (1997) Molecular basis for the interaction of [Nle4,D-Phe7]melanocyte stimulating hormone with the human melanocortin-1 receptor. J Biol Chem 272:23000-23010.

Yang Z, Han S, Keller M, Kaiser A, Bender BJ, Bosse M, Burkert K, Kögler LM, Wifling D, Bernhardt G, et al. (2018) Structural basis of ligand binding modes at the neuropeptide $\mathrm{Y}_{1}$ receptor. Nature 556:520-524.

Yin J, Babaoglu K, Brautigam CA, Clark L, Shao Z, Scheuermann TH, Harrell CM, Gotter AL, Roecker AJ, Winrow CJ, et al. (2016) Structure and ligand-binding mechanism of the human OX1 and OX2 orexin receptors. Nat Struct Mol Biol 23: 293-299.

Yin J, Chapman K, Clark LD, Shao Z, Borek D, Xu Q, Wang J, and Rosenbaum DM (2018) Crystal structure of the human $\mathrm{NK}_{1}$ tachykinin receptor. Proc Natl Acad Sci USA 115:13264-13269.

Yin J, Mobarec JC, Kolb P, and Rosenbaum DM (2015) Crystal structure of the human OX2 orexin receptor bound to the insomnia drug suvorexant. Nature 519: $247-250$.

Address correspondence to: Dr. Irina G. Tikhonova, School of Pharmacy, Medical Biology Centre, 97 Lisburn Road, Queen's University Belfast, Belfast BT9c7BL, Northern Ireland, United Kingdom. E-mail: i.tikhonova@qub.ac.uk 